\title{
Techniques for remediation of Mercury(II) from wastewater-A Review
}

\author{
Sophie Beulah $\mathrm{S}^{1}$ | Muthukumaran $\mathrm{K}^{2}$ \\ ${ }^{1}$ Department of Chemistry, Government College of Engineering, Tirunelveli, Tamilnadu, India. \\ ${ }^{2}$ Department of Chemistry, Government College of Technology, Coimbatore, Tamilnadu, India.
}

To Cite this Article

Sophie Beulah S and Muthukumaran K, "Techniques for remediation of Mercury(II) from wastewater-A Review", International Journal for Modern Trends in Science and Technology, Vol. 06, Issue 07, July 2020, pp.:106-112; https://doi.org/10.46501/IJMTST060717

Article Info

Received on 17-June-2020, Revised on 21-June-2020, Accepted on 31-June-2020, Published on 17-July-2020.

\section{ABSTRACT}

The toxicity of heavy metal ions released by industrial effluents is a huge concern to public health. Heavy metal ions are toxic even at trace level concentrations and can accumulate in living organisms, causing several disorders and diseases. One of the most potential among them is the toxic Hg(II). Mercury contamination in water is a widespread problem, not just locally but also globally. This article reviews the available literature on the remediation of $\mathrm{Hg}(\mathrm{II})$ from wastewater by various methods.

KEYWORDS: Heavy metal ions, $H g(I I)$, adsorbents, wastewater

Copyright (C) 2020 International Journal for Modern Trends in Science and Technology

DOI: https://doi.org/10.46501/IJMTST060717

\section{INTRODUCTION}

Though there has been plenty of water on earth, fresh water has not always been available when and where it is needed, nor is it always of suitable quality for all uses. Of recent origin the world has witnessed industrial spurge and industrialization has led to inferior quality of water sources. Contamination of heavy metal ions from industrial effluents makes water unsuitable for use. Hence there is an urgent need of elimination of the toxic heavy metal ions from wastewater.

Heavy metals are generally considered to be those whose density exceeds $5 \mathrm{~g}$ per cubic centimeter. A large number of elements fall into this category. Mercury $(\mathrm{Hg})$ is a d-block element with an atomic number 80 and is in liquid form under standard conditions. Mercury is found in deposits of mercuric sulfide called cinnabar. Mercury pollution is caused by pharmaceutical industries, pulp and paper preservation, caustic soda production industry, agriculture industry, etc. Mercury poisoning is called pink disease also known as acrodynia. Elevated exposure levels of mercury in any form can damage the kidneys, brain, developing fetus, etc. Mercury exposure can also cause lung damage, skin rashes, memory problems, and hair loss[1]. The permissible limit of $\mathrm{Hg}(\mathrm{II})$ in potable water is $0.002 \mathrm{mg} / \mathrm{L}$ as per USEPA (United States Environment Protection Agency) standard[2] and $0.001 \mathrm{mg} / \mathrm{L}$ as per Indian standard[3]. So it is highly imperative to decontaminate it from wastewater.

A number of studies on mercury(II) removal from wastewater have been reported. This paper presents a review of the selected literature dealing with the removal of mercury(II) using various techniques. 


\section{VARIOUS TECHNIQUES IN HEAVY METALS REMOVAL FROM WASTE WATER}

The conventional processes for removing heavy metal ions from wastewater includes chemical precipitation, flotation, adsorption, membrane filtration, ion exchange etc. In chemical precipitation, adjustment of $\mathrm{pH}$ to the basic conditions ( $\mathrm{pH} 9-11)$ is the major parameter that significantly improves heavy metal ions removal. Lime and limestone are the most commonly employed precipitant agents due to their availability and low-cost in most countries Lime precipitation can be employed to effectively treat inorganic effluent with metal ions concentration of higher than $1000 \mathrm{mg} / \mathrm{L}$. Other advantages of using lime precipitation include the simplicity of the process, inexpensive equipment requirement, and convenient and safe operations. However, chemical precipitation requires a large amount of chemicals to reduce metals to an acceptable level for discharge. Other drawbacks are its excessive sludge production that requires further treatment, slow metal precipitation, poor settling, the aggregation of metal precipitates, and the long-term environmental impacts of sludge disposal [4]

Ion exchange is another method used successfully in the industry for the removal of heavy metal ions from effluent. An ion exchanger is a solid capable of exchanging either cations or anions from the surrounding materials. Commonly used matrices for ion exchange are synthetic organic ion exchange resins. The disadvantage of this method is that it cannot handle concentrated metal ions solution as the matrix gets easily fouled by organics and other solids in the wastewater. Moreover ion exchange is nonselective and is highly sensitive to the $\mathrm{pH}$ of the solution. Electrolytic recovery or electro-winning is one of the many technologies used to remove metals from process water streams. This process uses electricity to pass a current through an aqueous metal-bearing solution containing a cathode plate and an insoluble anode. Positively charged metal ions cling to the negatively charged cathodes leaving behind a metal deposit that is strippable and recoverable. A noticeable disadvantage is that corrosion could become a significant limiting factor, where electrodes would frequently have to be replaced[5].

Electrocoagulation has been proposed as another effective method to treat various wastewaters such as landfill leachate, restaurant wastewater, tar sand and oil shale wastewater urban wastewater, laundry wastewater and chemical mechanical polishing wastewater. Electrocoagulation produces by anodic dissolution followed by hydrolysis, aluminum or iron hydroxide flocs which destabilise and aggregate the suspended particles or precipitates and absorb dissolved contaminants. It has some significant advantages namely; simple equipment and easy operation and automation, a shorter retention time, high sedimentation velocities, more easily dewatered, reduced amount of sludge due to the lower water content[6].

Membrane filtration is a technique that can be used for the removal of contaminants from water. Membranes are synthetic materials with pores acting as selective barriers, which do not allow some constituents of the water to pass through. A driving force, such as pressure difference between the feed and the permeate sides, is needed to transport the water through the membrane. Generally, there are two categories of pressure-driven membrane filtrations: (i) low-pressure membrane processes, such as microfiltration and ultrafiltration and (ii) high-pressure membrane processes, such as reverse osmosis and nanofiltration[7]

Adsorption is the process where molecules are concentrated on the surface of the sorbent. The molecules go from the bulk phase to being adsorbed in the pores in a semiliquid state. The driving force for adsorption is the ratio of the concentration to the solubility of the compound. A variety of natural and synthetic materials has been used as sorbents, including activated carbons, biological materials, zeolites, chitosan, and industrial wastes. Adsorption offers significant advantages like low cost, availability, profitability, easy operation and efficiency, in comparison with other conventional methods especially from economical and environmental points of view[8].

Flotation is yet another separation process, based on the introduction of gas bubbles as the transport medium. Suspended particulate matter, being hydrophobic or conditioned to be so, is then attached to the bubbles and moves toward the water solution surface, contrary to the direction of gravity. Ion flotation involves the removal of surface-inactive ions from aqueous solutions by adding surfactants or collectors, usually with an ion having a charge opposite to that of the metal ion to be removed. Dilute aqueous solutions has been extensively investigated in the laboratory with batch-scale and continuous mode experiments by applying the sorptive flotation technique. This 
method involves the preliminary abstraction or scavenging of metal ions using proper "sorbents", which exist at the fine or ultrafine particle-size range, followed by a subsequent flotation stage for the separation of metal-loaded sorbent particles from the treated solution[9]. In view of the above, several methods such as adsorption, chemical precipitation, reverse osmosis, ion-exchange, flotation etc have been reported for heavy metals removal. Table I presents the advantages and disadvantages of mercury removal techniques[10].

\section{LITERATURE REVIEW}

Satish I. Chaturvedi(2013) studied the removal of mercury from mercury containing waste water prepared synthetically by using sodium chloride as an electrolyte using sacrificial aluminum anode in a batch wise by electrocoagulation cell. The wastewater was obtained from a tank containing a mixture of exhaust dyeing solutions at a textile factory. The effect of applied potential, initial $\mathrm{pH}$, initial concentration of solution, agitation, electrolyte concentration and energy consumption on percent removal of mercury have been investigated. The removal efficiency of mercury was 98.5\% under optimum condition in which solution $\mathrm{pH}$ was 4.5 , applied potential $9 \mathrm{~V}$, initial solution concentration $50 \mathrm{ppm}$, electrolyte concentration $1.333 \mathrm{~g} /$ lit. with a stirring speed $400 \mathrm{rpm}[11]$.

Andrea. J. Santana et al.(2016) investigated powders obtained from the peel of the fruit of Pachira aquatica Aubl, in its in natura and/or acidified form, as an adsorbent for the removal of mercury ions in aqueous solution. The materials were characterized by Fourier Transform Infrared Spectroscopy and Thermogravimetric analysis. Batch experiments were done. The adsorption process was evaluated using Cold-Vapor Atomic Fluorescence Spectrometry and Cold-Vapor Atomic Absorption Spectrometry. The adsorption isotherm model, Langmuir-Freundlich, based on the performances best represented the adsorption process, and the maximum adsorption capacity was predicted at 0.71 and $0.58 \mathrm{mg} \mathrm{g}-1$ at $25^{\circ} \mathrm{C}$ in nature and acidified, respectively. The pseudo-second order model showed the best correlation to the experimental data. The presence of the metal ions interference $\mathrm{Cd}(\mathrm{II}), \mathrm{Pb}(\mathrm{II}), \mathrm{Cu}(\mathrm{II})$ in examined concentrations, on the adsorption of $\mathrm{Hg}$ in biomass, in its in natura and acidified form, generally was unaffected. For adsorption on real aqueous wastewater sample the \% removal of $\mathrm{Hg}(\mathrm{II})$ was as $69.6 \%$ for biomass acidified and $76.3 \%$ for biomass in nature. [12]
Qing-Zhou Zhai(2014) prepared nanometer $\mathrm{a}-\mathrm{Al}_{2} \mathrm{O}_{3}$ powders by solid state method which was used as the adsorbent and powder X-ray diffraction and scanning electron microscopy were used to characterize the prepared powders. Mercury stock standard solution was prepared from mercury nitrate. Mercury(II) content determination was accomplished on a Spectrophotometer Effects of $\mathrm{pH}$, adsorption contact time, initial concentration of $\mathrm{Hg}(\mathrm{II})$,adsorbent dosage and effect of temperature was analysed. The optimal adsorption conditions for the initial $\mathrm{Hg}$ (II) concentration of $0.80 \mathrm{mg} / \mathrm{ml}, \mathrm{a}-\mathrm{Al}_{2} \mathrm{O}_{3}$ amount : $\mathrm{Hg}(\mathrm{II})$ amount $(\mathrm{g} / \mathrm{g})$ $=4.17, \mathrm{pH}=3.5$, contact time $10 \mathrm{~min}$, temperature $20^{\circ} \mathrm{C}$. The effects of desorption of three type desorptive agents $\mathrm{CH}_{3} \mathrm{COOH}, \mathrm{HNO}_{3}, \mathrm{HCl}$, were probed. The optimal desorption agent was 0.10 $\mathrm{mol} / \mathrm{L} \mathrm{HCl}$. When desorption was $10 \mathrm{~min}$, the highest desorption rate was $97.92 \%$. The maximum adsorptive amount of $\mathrm{Hg}$ (II) was 157.8 $\mathrm{mg} \mathrm{Hg}(\mathrm{II}) / \mathrm{g}\left(\mathrm{a}-\mathrm{Al}_{2} \mathrm{O}_{3}\right)$ [13].

Erhayem, M., Al-Tohami et al.(2015) dealt with the equilibrium adsorption of $\mathrm{Hg}$ (II) onto carbonized Rosmarinus officinalis leaves as adsorbent from aqueous solution. Samples were prepared by physical carbonization at $773 \mathrm{~K}$ for 1 h. Titration method was used to determine the concentration of $\mathrm{Hg}(\mathrm{II})$ before and after adsorption by ethylenediaminetetraacetic acid, EDTA, as chelating agent. Batch equilibrium studies were carried out under different experimental conditions such as $\mathrm{Hg}(\mathrm{II})$ concentration and temperature. The equilibrium sorption data were analyzed using Freundlich, Langmuir, Dubinin-Ra-dushkevich (DRK) and Temkin isotherms. The experimental results were found to fit the Langmuir isotherm model with a monolayer adsorption capacity of $588.2 \mathrm{mg} / \mathrm{g}$ at $318 \mathrm{~K}$, while they were found to fit the Freundlich isotherm model at $298 \mathrm{~K}$. The thermodynamic studies revealed that the process is spontaneous in nature and exothermic [14].

Jeriffa De Clercq(2012) analysed the performance of two adsorbents, a stable mesoporous adsorbent, i.e. a thiol containing ethene bridged periodic mesoporous organosilica SH-ePMO and a commercial ion exchange resin TP-214, for the removal of mercury from aqueous solutions. Batch adsorption studies were done. The operating variables studied were initial mercury concentration and contact time The adsorption isotherms were studied using Langmuir and Freundlich models. The Langmuir model yielded the best fit for the SH-ePMO, whereas the Freundlich model fitted best the adsorption on 
TP-214. The maximum adsorption capacities were 66 and $456 \mathrm{mg} / \mathrm{g}$ for SH-ePMO and TP-214, respectively. The lower capacity of SH-ePMO was attributed to its small amount of thiol groups The pseudo-first-order kinetic model showed a good description of the experimental data of both adsorbents. TP-214 was capable of purifying water to parts per trillion levels. [15].

E Vélez et al(2016). developed $\mathrm{Fe}_{3} \mathrm{O}_{4}$ and $\gamma-\mathrm{Fe}_{2} \mathrm{O}_{3}$ nanoparticles using iron salts and $\mathrm{NaOH}$ as precipitation agents, and Aloe Vera as stabilizing agent. Aloe Vera was used as stabilizing agent because of its low cost, and non-toxicity. Iron oxide nanoparticles are efficient adsorbents because they combine magnetic separation with ionic exchange capacity for heavy metals removal. The nanoparticles were characterized by three different measurements: using a Zetasizer Nano ZS for their size estimation, UV-visible spectroscopy which showed the existence of resonance of plasmon at $\lambda \max \sim 360 \mathrm{~nm}$, and by Scanning Electron Microscopy (SEM) to determine nanoparticles form. At any concentration value of iron oxide nano particles, the removal percentage of $\mathrm{Hg}(\mathrm{II})$ was above $60 \%$, therefore it was not necessary to use high concentrations of nanoparticles for effective removal of mercury. Mercury removal of $70 \%$ approximately reported was confirmed by atomic absorption spectroscopy measurements[16].

Rahmanzadeh $\mathbf{L}$ et al(2016) assessed the adsorbent, magnetite-polyrhodanine core- shell nanoparticles for removing $\mathrm{Hg}$ (II) from aqueous solution. Different parameters like, effect of $\mathrm{pH}$, initial $\mathrm{Hg}$ (II) concentration, initial adsorbent concentration and contact time on the efficiency of $\mathrm{Hg}$ (II) removal were investigated by batch experiments. The maximum adsorption capacity was obtained at $\mathrm{pH}=6.5$ and $25^{\circ} \mathrm{C}$ with $10 \mathrm{~g} \mathrm{~L}-1$ nano adsorbent. The kinetic data of adsorption of $\mathrm{Hg}(\mathrm{II})$ ion on the synthesized adsorbent were best described by a pseudo- second- order equation, indicating their chemical adsorption. The Freundlich, Langmuir and Temkin isotherms were used for modeling and modeled best by the Freundlich isotherm is whole concentration rage. The maximum adsorption capacity obtained was 29.14 mg g-1 [17].

\section{Shaojun Huang et al.(2016) applied} Poly(1-amino-5-chloroanthraquinone) nanofibrils as nanoadsorbents for mercury removal from aqueous solutions. A series of batch adsorption experiments were conducted to study the effect of adsorbent dose, $\mathrm{pH}$, contact time, and metal concentration on $\mathrm{Hg}(\mathrm{II})$ uptake by nanofibrils. Kinetic data indicated that the adsorption process of nanofibrils for $\mathrm{Hg}(\mathrm{II})$ achieved equilibrium within $2 \mathrm{~h}$ following a pseudo-second-order rate equation. The adsorption mechanism was investigated by Fourier transform-infrared (FT-IR) spectra and $\mathrm{X}$-ray photoelectron spectroscopy (XPS) analyses. Five consecutive adsorption-desorption cycles were done without considerable changes in the adsorption capacity to evaluate the practicability of the nanosorbent for purifying actual wastewater, a batch experiment was conducted on chloralkali wastewater. Nanoadsorbent exhibited a very high capability for adsorption of mercury ions (98.4\%) from chloralkali wastewater. The adsorption isotherm of $\mathrm{Hg}(\mathrm{II})$ fitted well the Langmuir model, exhibiting adsorption capacity of $3.846 \mathrm{mmol}$ of metal per gram of adsorbent[18].

Kamyar Yaghmaeian et al.(2015) revealed that carbon nanotubes which have tiny pores with uniform size and also wide specific surface have been used to remove pollutants. Multi-walled carbon nanotubes were used as sorbent to remove mercury from aqueous solution using batch technique. Cold vapour inductively coupled plasma optical emission spectrometry was used to determine the amount of mercury in solution. Effect of $\mathrm{pH}$, contact time and initial concentration of mercury were studied The best $\mathrm{pH}$ for adsorption was about 7 . The rate of adsorption process initially was rapid but it was gradually reduced with increasing of contact time and reached the equilibrium after $120 \mathrm{~min}$. More than $85 \%$ of initial concentration of $0.1 \mathrm{mg} / \mathrm{L}$ was removed at $0.5 \mathrm{~g} / \mathrm{L}$ concentration of sorbent and contact time of $120 \mathrm{~min}$. Adsorption process followed the pseudo second order model and the adsorption isotherms was described by both the Freundlich and the Langmuir models[19].

George Z. Kyzas et al(2013) investigated two modified chitosan derivatives prepared in order to compare their adsorption properties for $\mathrm{Hg}$ (II) removal from aqueous solutions. One chitosan adsorbent is only cross-linked with glutaraldehyde, while the other, which is magnetic, is cross-linked with glutaraldehyde and functionalized with magnetic nanoparticles $\left(\mathrm{Fe}_{3} \mathrm{O}_{4}\right)$. Many possible interactions between materials and $\mathrm{Hg}(\mathrm{II})$ were observed after adsorption and explained via characterization with various techniques (SEM/EDAX, FTIR, XRD, DTG, DTA, VSM, swelling tests). The adsorption evaluation was done studying various parameters as the effect of $\mathrm{pH}$ (optimum value 5 for adsorption and 2 for 
desorption), contact time (fitting to pseudo-first, -second order and Elovich equations), temperature (isotherms at $25,45,65{ }^{\circ} \mathrm{C}$ ). The maximum adsorption capacity (fitting with Langmuir and
Freundlich model) of at $25{ }^{\circ} \mathrm{C}$ was 145 and 152 $\mathrm{mg} / \mathrm{g}$, respectively[20]. The summary of the above literature is given as Table 2 .

Table 1. Advantages and disadvantages of mercury removal techniques[10]

\begin{tabular}{|l|l|l|}
\hline Removal techniques & Advantages & Disadvantages \\
\hline Ion exchange & $\begin{array}{l}\text { Fast kinetics. High capacity of } \\
\text { treatment. High removal efficiency }\end{array}$ & $\begin{array}{l}\text { Resins synthetic is costly. Serious } \\
\text { secondary pollution is caused by } \\
\text { regeneration of the resins. Waste products } \\
\text { are produced Selectivity is low. }\end{array}$ \\
\hline Adsorption & $\begin{array}{l}\text { Wide pH range. Low cost. Metal binding } \\
\text { capacities are high. Easy operation } \\
\text { conditions. }\end{array}$ & $\begin{array}{l}\text { Waste products are produced. Selectivity is } \\
\text { low. }\end{array}$ \\
\hline Chemical precipitation & $\begin{array}{l}\text { Operation is simple. Capital cost is low. } \\
\text { small space and low pressure. }\end{array}$ & $\begin{array}{l}\text { Generation of sludge. Sludge disposal } \\
\text { needs extra operational costs }\end{array}$ \\
\hline Membrane fltration & $\begin{array}{l}\text { High metal selectivity and removal } \\
\text { effciency. More concentrated sludge is } \\
\text { produced. }\end{array}$ & $\begin{array}{l}\text { Hembrane fouling is expensive. Process is } \\
\text { operation cost. }\end{array}$ \\
\hline Flotation &
\end{tabular}

Table 2. The summary of the above literature

\begin{tabular}{|c|c|c|c|c|}
\hline Authors name & Method of removal of $\mathrm{Hg}(\mathrm{II})$ & Optimum & Concentration & \%Removal/Adsorption \\
\hline $\begin{array}{l}\text { Satish I. } \\
\text { Chaturvedi(201 } \\
\text { 3) }\end{array}$ & Electrocoagulation cell & $\begin{array}{l}\mathbf{p n} \\
4.5\end{array}$ & $30-100 \mathrm{ppm}$ & 98.5 \\
\hline $\begin{array}{l}\text { Andrea. J. } \\
\text { Santana et } \\
\text { al.(2016) }\end{array}$ & $\begin{array}{l}\text { Adsorption- Peel of fruit of Pachira } \\
\text { aquatic Aubl in natura and acidified } \\
\text { form }\end{array}$ & 4 & $50 \mu \mathrm{g} \mathrm{L}-1$ & $\begin{array}{l}\text { For real aqueous } \\
\text { wastewater samples( } \\
\text { dental waste) } 69.6 \% \text { for } \\
\text { biomass acidified ad } \\
76.3 \% \text { for biomass in } \\
\text { nature }\end{array}$ \\
\hline $\begin{array}{l}\text { Qing-Zhou } \\
\text { Zhai(2014) }\end{array}$ & $\begin{array}{l}\text { Adsorption-nanometer } \mathrm{a}-\mathrm{Al}_{2} \mathrm{O}_{3} \\
\text { powders }\end{array}$ & 3.5 & $\begin{array}{l}0.1,0.3,0.5 \\
0.8, \quad 1.0 \\
\mathrm{mg} / \mathrm{mL}\end{array}$ & $\begin{array}{l}\text { Maximum adsorptive } \\
\text { amount is } 157.8 \mathrm{mg} \\
\mathrm{Hg}(\mathrm{II}) / \mathrm{g}\left(\mathrm{a}-\mathrm{Al}_{2} \mathrm{O}_{3}\right)\end{array}$ \\
\hline $\begin{array}{l}\text { Erhayem, M., } \\
\text { Al-Tohami et } \\
\text { al.(2015) }\end{array}$ & $\begin{array}{l}\text { Adsorption-Rosmarinus officinalis } \\
\text { leaves }\end{array}$ & 2.4 & $100-400 \mathrm{mg} / \mathrm{L}$ & $588.2 \mathrm{mg} / \mathrm{g}$ \\
\hline $\begin{array}{l}\text { Jeriffa De } \\
\text { Clercq(2012) }\end{array}$ & $\begin{array}{l}\text { Adsorption and Ion exchange } \\
\text { (mesoporous organosilica SH-ePMO } \\
\text { and a commercial ion exchange resin) } \\
\text { TP-214, }\end{array}$ & - & $0-900 \mathrm{ppm}$ & $\begin{array}{l}66 \text { and } 456 \mathrm{mg} / \mathrm{g} \text { for } \\
\text { SH-ePMO and TP-214 }\end{array}$ \\
\hline E Vélez et & Adsorption- $\mathrm{Fe}_{3} \mathrm{O}_{4}$ and $\gamma-\mathrm{Fe}_{2} \mathrm{O}_{3}$ & - & 4 to $50 \mathrm{mg} / \mathrm{L}$ & More than $87 \%(70 \%$ \\
\hline
\end{tabular}




\begin{tabular}{|c|c|c|c|c|}
\hline al(2016). & nanoparticles & & & average) \\
\hline $\begin{array}{l}\text { Rahmanzadeh L } \\
\text { et al(2016) }\end{array}$ & $\begin{array}{l}\text { Adsorption- magnetite-polyrhodanine } \\
\text { core- shell nanoparticles }\end{array}$ & 6.5 & 50 to $300 \mathrm{mg} / \mathrm{L}$ & $29.14 \mathrm{mg} \mathrm{g}-1$ \\
\hline $\begin{array}{l}\text { Shaojun Huang } \\
\text { et al.(2016) }\end{array}$ & $\begin{array}{l}\text { Adsorption-Poly(1-amino-5-chloroant } \\
\text { hraquinone) (PACA) nanofibrils }\end{array}$ & 6 & $10 \mathrm{mmol} \mathrm{L}-1$ & $\begin{array}{l}3.846 \mathrm{mmol} \text { of metal per } \\
\text { gram of adsorbent }\end{array}$ \\
\hline $\begin{array}{l}\text { Kamyar } \\
\text { Yaghmaeian et } \\
\text { al.(2015) }\end{array}$ & $\begin{array}{l}\text { Adsorption-Multiwalled carbon nano } \\
\text { tube }\end{array}$ & 7 & 0.1 to $10 \mathrm{mg} / \mathrm{L}$ & $25.641 \mathrm{mg} / \mathrm{g}$ \\
\hline $\begin{array}{l}\text { George } Z \text {. Kyzas } \\
\text { et al(2013) }\end{array}$ & $\begin{array}{l}\text { Adsorption-chitosan adsorbent is only } \\
\text { cross-linked with glutaraldehyde, } \\
\text { while the other, which is magnetic, is } \\
\text { cross-linked with glutaraldehyde and } \\
\text { functionalized with magnetic } \\
\text { nanoparticles }\left(\mathrm{Fe}_{3} \mathrm{O}_{4}\right) \text {. }\end{array}$ & 5 & $100 \mathrm{mg} / \mathrm{L}$ & 145 and $152 \mathrm{mg} / \mathrm{g}$ \\
\hline
\end{tabular}

This review has established that the removal of the mercury(II) by the different methodologies are highly effective and promising results have been reported based on the adsorption capacity and \% removal. It is evident from the literature survey that adsorption method is widely used over conventional methods and different types of adsorbents have been employed by the researchers for the effective removal of $\mathrm{Hg}$ (II).

\section{CONCLUSION}

In this paper, an attempt has been made to review various techniques of mercury(II) removal from wastewater which established that adsorption has been used widely for the remediation of mercury(II) from wastewater. The future works can be added for the removal of mercury(II) from the onsite industrial effluents. These studies could be extended for analyzing the effects of other heavy metal ions present in the aqueous solution.

\section{V.REFERENCES}

[1] Rabia Baby, Bullo Saifullah and Mohd Zobir Hussein (2019). Carbon Nanomaterials for the Treatment of Heavy Metal-Contaminated Water and Environmental Remediation, Nanoscale Res. Lett. 14:341

[2] Federal Register (1975). 40: 11990

[3] Indian Standards (1982).75:2296

[4] Aziz, H A, Adlan M N, Ariffin, K S( 2008). Heavy metals (Cd, $\mathrm{Pb}, \mathrm{Zn}, \mathrm{Ni}, \mathrm{Cu}$ and $\mathrm{Cr}(\mathrm{III})$ ) removal from water in Malaysia: post treatment by high quality limestone, Bioresour. Technol. 99: 1578-1583.

[5] Barakat M A(2011). New trends in removing heavy metals from industrial wastewater, Arab. J. Chem. 4:361-377.

[6] Can O T, Kobya M , Demirbas E, Bayramoglu M(2006). Treatment of the textile wastewater by combined electrocoagulation, Chemosphere 6: 181-187.

[7] Nina Ricci Nicomel, Karen Leus, Karel Folens, Pascal Van Der Voort and Gijs Du Laing(2016). Technologies for
Arsenic Removal from Water: Current Status and Future Perspectives, Int. J. Environ. Res. Public Health. 13:62

[8] Mojdeh Owlad, Mohamed Kheireddine Aroua, Wan Ashri Wan Daud and Saeid Baroutian(2008). Removal of hexavalent chromium contaminated water and wastewater: A review, Water Air Soil Pollut..200:59-77.

[9] George Z. Kyzas ID and Kostas A. Matis(2018). Flotation in Water and Wastewater Treatment, Processes 6:116.

[10]MohammadA.Al-Ghouti, Dana Da'ana, MohammedAbu-Dieyeh and Majeda Khraisheh(2019).Adsorptive removal of mercury from water by adsorbents derived from date pits, Scientific Reports 9:15327.

[11] Satish I. Chaturvedi(2013). Mercury Removal Using Al - Al Electrodes by Electrocoagulation, Int. J. Mod. Eng. Res. 3:109-115.

[12] Andrea. J. Santana, Walter. N. L. dos Santos, Laiana O. B. Silva and Cesário F. das Virgens(2016). Removal of mercury(II) ions in aqueous solution using the peel biomass of Pachira aquatica Aubl: kinetics and adsorption equilibrium studies, Environ. Monit. Assess. 188:293

[13] Qing-Zhou Zhai(2014). Nano a- $\mathrm{Al}_{2} \mathrm{O}_{3}$ for removal of $\mathrm{Hg}(\mathrm{II})$ from water: Adsorption and desorption studies, J. Chem. and Pharma. Res. 6:1310-1317.

[14] Erhayem, M, Al-Tohami F, Mohamed R. and Ahmida K (2015). Isotherm, Kinetic and Thermodynamic Studies for the Sorption of Mercury(II) onto Activated Carbon from Rosmarinus officinalis Leaves, Am. J. Analyt. Chem. 6:1-10.

[15] Jeriffa De Clercq(2012). Removal of mercury from aqueous solutions by adsorption on a new ultra stable mesoporous adsorbent and on a commercial ion exchange resin, Int. J. Ind.Chem. 3:1

[16] Vélez E, Campillo G E, Morales G, Hincapié C, Osorio J , Arnache O, Uribe J I and Jaramillo F(2016). Mercury removal in wastewater by iron oxide nanoparticles, J. Phys. Conference Series 687: 012050.

[17] Rahmanzadeh L, Ghorbani M, Jahanshahi M(2016). Effective removal of hexavalent mercury from aqueous solution by modified polymeric nanoadsorbent. J. Water Environ.. Nanotechnol.. 1:1-8.

[18] Shaojun Huang, Chengzhang Ma, Yaozu Liao, Chungang Min, Ping Du, and Yubo Jiang(2016). Removal of Mercury(II) from Aqueous Solutions by Adsorption on Poly(1-amino-5-chloroanthraquinone) Nanofibrils: 
Equilibrium, Kinetics, and Mechanism Studies, J. Nanomater. P.11

[19] Kamyar Yaghmaeian , Reza Khosravi Mashizi, Simin Nasseri, Amir Hossein Mahvi, Mahmood Alimohammadi and Shahrokh Nazmar (2015). Removal of inorganic mercury from aquatic environments by multi-walled carbon nanotubes, J. Environ. Health Sci. Eng. 13:55.

[20] George Z. Kyzas and Eleni A. Deliyanni(2013). Mercury(II)

Removal with Modified Magnetic Chitosan Adsorbents, Molecules 18:6193-6214.

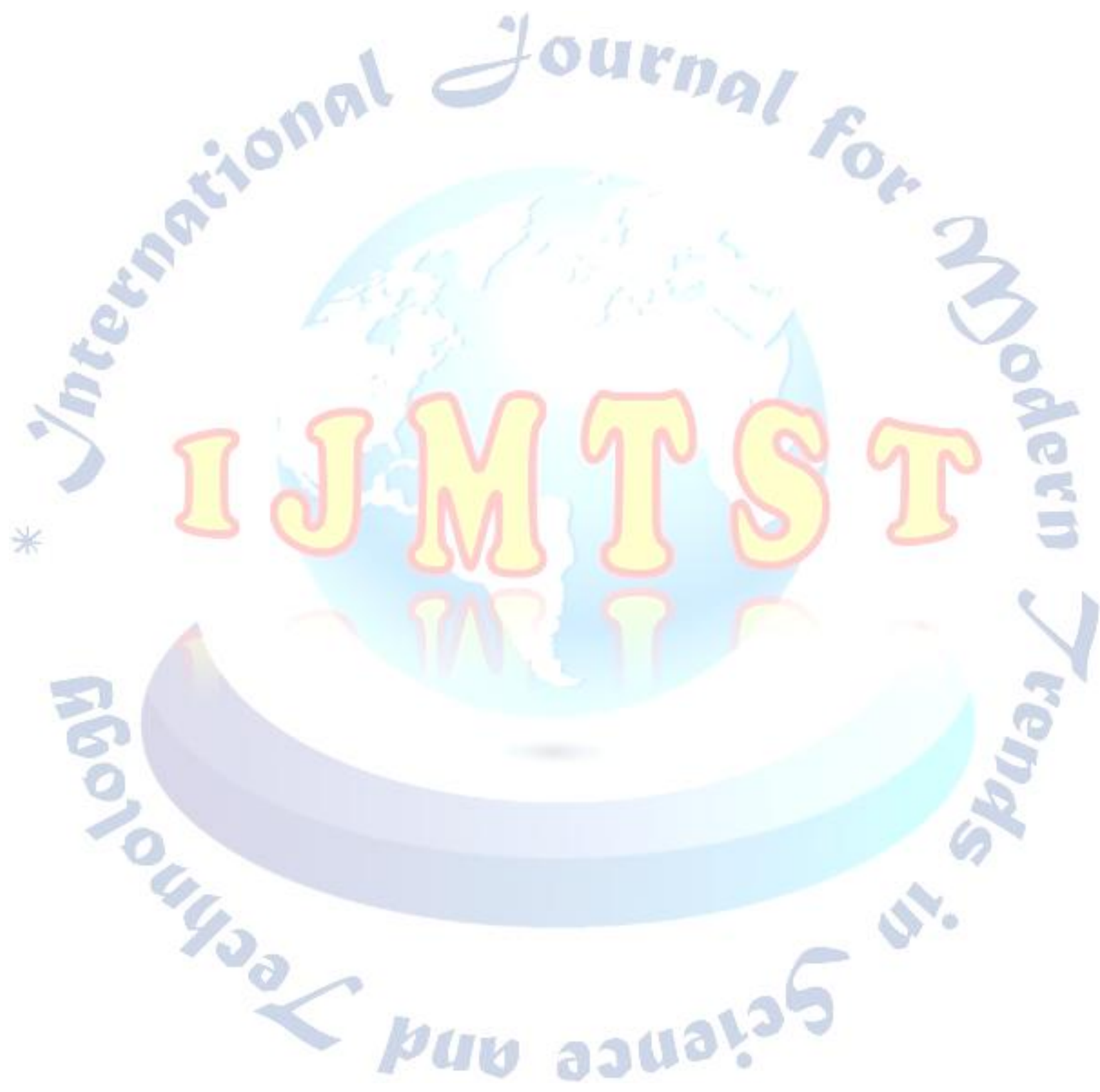

